\title{
Falusi fiatalok identitásának szociális reprezentációja
}

\author{
MURÁNYI ISTVÁN ${ }^{1}$
}

\begin{abstract}
ABSZTRAKT
A tanulmányban a szociális reprezentáció elmélete és annak egyik módszere (asszociációs módszer) alapján vizsgáljuk a szocio-kulturális jellemzők szerint kialakított csoportok lokális és én identitásának jellemzőit. A falusi fiatalok mintáján elvégzett elemzés arra irányult, hogy milyen kapcsolat van az identitás szociális reprezentációja alapján elkülöníthető, a jelentéstartalmakat eltérő intenzitással kifejező négy csoport és a szociológiai háttérváltozók szerint kialakított csoportok között. A várt eredmények mellett az érzelmi kötődés és a mobilitás változók esetében megfigyelhető ellentmondás hipotetikus magyarázatát további kutatásokkal lehet empirikusan igazolni.
\end{abstract}

KULCSSZAVAK: szociális reprezentáció, lokális identitás, fiatalok

\section{ABSTRACT}

\section{Social representation of rural youth identity}

In this paper, we investigate the local and self-identity characteristics of socio-cultural groups based on social representation theory and one of its methods (association method). Carried out on a sample of rural youth, the analysis focused on the relationship between the four groups, distinguished by their social representations of identity, with different intensities of meaning and the sociological background variables. In addition to the expected results, the hypothetical explanation for the contradiction in the emotional attachment and mobility variables can be further empirically confirmed.

KEYWORDS: social representation, local identity, youth

Tanulmányunkban az MTA Kiválósági Együttműködési Program keretében lebonyolított „Immobil falusi fiatalok” kutatás adatai alapján a 18-25 éves almintára jellemző én- és lokális identitás szociális reprezentációját elemezzük. Az elemzés a kutatás

\footnotetext{
${ }^{1}$ Egyetemi docens, Debreceni Egyetem Szociológia és Szociálpolitika Tanszék, muranyi.istvan@arts. unideb.hu
} 


\section{TEMATIKUS TANULMÁNYOK - KöZségekben élő immobil fiatalok}

során készült interjúszövegekre (53 fős, nem valószínűségi minta) valamint az interjúk kategoriális feldolgozására támaszkodunk.

\section{Bevezetés}

A lokális identitás szociológiai vizsgálatának átfogó elméleti keretének a szociális identitás elméletét (Tajfel 1978, 1982, Tajfel - Turner 1979), a szociális reprezentáció elméletét (Moscovici 1984, 1988) és Krappmann „egyensúlyozó identitás” elméletét (Krappmann 1980) tekintettük megfelelő alapnak.

A relevánsnak tekinthető hazai identitás értelmezések (Pataki 1982, Csepeli 1995, Erős 1996) kivétel nélkül kapcsolódnak a társadalomtudományban meghatározó szerepet játszó Erik H. Erikson definíciójához, mely szerint az identitás a személyes azonosság és folyamatosság szubjektív érzésének megléte, amely egy közös világkép azonosságában és folyamatosságában való hittel párosul (Erikson 1991). Azonban számolni kell azzal is, hogy a szociális identitás kategóriájával azonosított identitás túlságosan általános, minden kollektív tudatformára történő alkalmazásának következménye a fogalom egyfajta „inflálódása”: „[A]mi korábban a fogalomhasználat előnyének tűnt, az ma inkább hátrány. Az identitás társadalmi konstrukcióként történő felfogása ugyanis hovatovább megfoghatatlanná teszi azt, ami a folyton változóban állandó, amire tehát az identitás fogalma eredetileg vonatkozott." (Gyáni 2008: 20).

Az identitás társadalomtudományi - szűkebben szociológiai - értelmezésénél természetesen nem lehet eltekinteni az elmélet narratív fordulatának (Olick - Robbins 1998) vagy a különösen a történettudományban egyre markánsabban jelen lévő emlékezet elméletek - Halbwachs, Nora, Assmann, Ricouer - hatásától, melyek a kollektív emlékezet fő funkciójának tartják az identitás kialakítását és megtartását (Gyáni 2008). Többen úgy vélik, hogy az identitás egy narratív formában történő konstrukció (Bruner 1990, Calhoun 1994), de ennél markánsabb vélemények is vannak: „a személyes identitás fogalmának [kiterjesztve a csoportidentitásra is] fogalmának minden magyarázat-kísérlete bukásra ítélt, ha független és elkülönített a narratíva fogalmától." (MacIntyre 1984: 45)

A hazai társadalomtudományi szakirodalom nem bővelkedik megfelelő elméleti háttérbe illeszkedő és operacionalizálható lokális identitás értelmezéssel. A különböző meghatározási kísérletek más-más diszciplinához kapcsolódnak.

A történeti-földrajzi kötődések alapján szerveződő lokális identitás szociológiai vagy társadalomföldrajzi tárgyalására csak elvétve találunk példát a hazai szakirodalomban (Bőhm - Pál, 1987, Köteles - Varga 1988, Enyedi 1991, Bőhm 2000).

Az antroplógiai megközelítések közül A. Gergely András a lokális identitást egyszerre tartja a személyes („az önmeghatározás... fontos eszköze”) és a csoport szintű („a helyi közösség legfőbb önmeghatározási kritériuma”) identitás részének. A loká- 


\section{TEMATIKUS TANULMÁNYOK - Községekben élő immobil fiatalok}

lis (helyi) identitás általános (mindenkinek sajátja) és kiterjedésének, érvényességének relatív jellegét hangsúlyozza, de elveti az állandóságát, mivel az aktuális csoporttudat szintjének és környezeti hatásoknak a függvénye (A. Gergely 2011). Ez az értelmezés nem meglepő, mivel a szerző egy korábbi identitás értelmezésében sem különült el az identitás személyes és társadalmi dimenziója. ${ }^{2}$

A társadalomföldrajzhoz kapcsolódó értelmezés a lokális identitást egyfajta attitűdnek tekintő értelmezés meghatározható területi és térbeli dimenziókhoz való kötődésként szintén nem különíti el az egyén és a csoport szintjét. ${ }^{3}$

A kulturantroplógiai írások jelentős részének témája a lokális identitás, azonban a fogalom értelmezésére csak elvétve találunk példát. Ezek egyike Bakó Boglárka meghatározása, amely - szemben a másik két megközelítéssel - kizárja az egyéni szinthez kötött értelmezést. ${ }^{4} A$ tág értelmezési lehetőséget rejto „viszony” definíció mellett a szerző kiemeli a lokális identitás megnyilvánulásának (prezentálódásának) sokféleségét is (helyi rendezvények, kiadványok, emlékhelyek, eredetmítoszok).

Az MTA Regionális Kutatások Központja Alföldi Tudományos Intézetében a nyolcvanas évek közepétől folynak, elsősorban a földrajzi identitás térelemeivel foglalkozó, kisebb területekre (falvak, városrészek, kistérségek) koncentráló kutatások (Csatári 1989, Nánásiné 1996, Hamar - Murányi - Szoboszlai 1997, Murányi - Szoboszlai 1998, 1999). A kifejezetten lokális identitás vizsgálatára vállalkozó nagymintás kutatás során a lokális kötődés elemeinek kategorizálását konkrét terekhez rendeltük. A lokális identitást - Csepeli György nemzeti identitás értelmezésére építve - a társadalmi identitástudat szerves részeként értelmeztük, melynek alapján az egyén a perszonális kapcsolathálónál (network) tágabb, földrajzi kategóriákkal meghatározható társadalmi csoport tagjának érzi és vallja magát. Az operacionalizálás során lényeges szempontnak tekintettük, hogy milyen kategorizációt (lakóhely, kistérség, megye, régió) alapoz meg a csoport kijelölése, de ez nem jelentette a térbeli meghatározottság kizárólagosságát (Murányi - Szoboszlai 2000).

Az előzőekben jelzett elméleti és empirikus előzményekre támaszkodva, az „Immobil falusi fiatalok" kutatás során a a fiatalok lokális identitását konkrét elméleti háttérhez kapcsolódó kvantitatív, illetve kvalitatív módszereket alkalmazó operacionalizálás alapján vizsgáltuk.

\footnotetext{
${ }^{2}$ „[A]z identitást egyszerűen mint vonatkoztatási rendszert kezelem, amely társadalmi tárgyakra, csoportjelenségekre és társadalmi térre kiterjedő személyiség-szférát jelent számomra, egyben az 'én' és ‘ő', illetve 'mi' és 'mások' konfliktusainak redukált, átélt és társadalomtörténetileg örökített mintáját." (A. Gergely 1996: 5)

3 „,[A]z egyéneknek és kollektíváknak a térhez való kötődését, annak kulturális, emocionális, kognitív tartalmát, megnyilvánulásait kell értenünk, amelyek többségében a konkrét lokalitásra, a meghatározott, földrajzilag is körülhatárolható területre vonatkoznak." (Pálné 2000: 75).

4 „,[K]özösség(ek) viszonyát fejezi ki annak szülőfalujához, városához, utcájához, emlékhelyeihez és ezek „történeteihez”, „mítoszaihoz”, rokonsági, baráti, szomszédi kapcsolataihoz.” (Bakó 2003: 167).
} 


\section{TEMATIKUS TANULMÁNYOK - Községekben élő immobil fiatalok}

\section{A szociális reprezentáció elmélete}

A szociális reprezentáció meghatározása - „a közös jelentések egy konszenzuális világa, amiben a csoporttagok kommunikálnak és interakcióban vannak" Purkhardt 1993: 75) - és folyamata (lehorgonyzás és objektiváció) szorosan kapcsolódik a társadalmi identitáshoz. Azt is mondhatjuk, hogy megmagyarázza a csoporttagok interpretációját és ábrázolását jelentőségteljes világukról. A közös jelentésekre (szociális reprezentációkra) való hivatkozással a csoporttagoknak elérhető, hogy a szociális reprezentáció folyamatai direkt megérthetők a szociális identitások kialakulásával. A szociális reprezentáció elmélete ily módon egy közeli kapcsolatot feltételez a szociális reprezentáció és a csoportfolyamatok, különösen a szociális identitás létrehozása és kifejezése között. Eddig kevés kísérlet volt a szociális reprezentáció és az identitás kapcsolatának részletes leírására (Millward 1995). A szociális reprezentáció identitásképző funkciója egyrészt abban nyilvánul meg, hogy a csoport minden tagja osztozik ezekben a reprezentációkban, másrészt a csoport meghatározza tagjai számára, hogy a különböző reprezentációk között milyen kapcsolatot létesíthet; vagyis korlátozza az asszociációs szabadságot, ezáltal előír egy a csoportra jellemző olyan szemléleti módot, amely mentén a csoport megkülönböztetheti magát más csoportoktól (Vincze - Kőváriné 2003). A szociális reprezentációk integrálják az egyéni gyakorlatokat, ugyanakkor kollektív szociális normákat, értékeket és tudásokat prezentálnak (Meier - Kirchler 1998). A kollektív identitás egy minden csoportban létező szociális reprezentációnak (magnak) tekinthető, mivel a csoporthoz mint közösséghez tartozás a sajátos szociális csoportok reprezentációján belüli lehorgonyzással történik és kifejezi a csoport egyedülállóságát, aktualitását és történelmét. A kollektív identitás egyesíti a reprezentációs rendszer azon aspektusait, amelyeket az egyén leginkább értékesnek, történelmileg állandónak és a különleges tulajdonságokat kifejezőnek érzékel (Asher et al. 2006). A csoportban zajló interakciók során keletkező szociális reprezentációk gyakran narratív formában jelennek meg, biztosítva a csoport történetiségét és időbeni folytonosságát (Vincze -Kőváriné 2003).

A szociális reprezentáció elmélete, illetve az „eredeti” teóriához kapcsolódó további elméletek (Wagner, Jovchelovitch, Bauer - Gaskell, Caroline Horvath, László János, Abric és munkatársai, Wagner, Gerard Duveen, Jodelet) közül Abric „központi mag elméletét" (Central Nucleus Theory - NT) módosított modelljét alkalmaztuk az interjú szövegekben olvasható válaszok elemzésére. A központi mag elmélete (CNT) Moscovici szociális reprezentáció általános elméletéhez (1976) kapcsolódó kiegészítő megközelítés. A központi mag gondolatát elsőként Jean-Claude Abric (1994a) javasolta, a megközelítés elméleti és módszertani továbbfejlesztéséhez más kutatók (P. Verges, Ch. Gruimelli, M-L. Rouquette, P. Moliner és M. Morin) is hozzájárultak. A CNT feltevéseinek és téziseinek részletes ismertetését mellőzve, az elmélet logikáját és a kapcsolódó módszertani keretet foglaljuk össze (Sá 1995). 


\section{TEMATIKUS TANULMÁNYOK - Községekben élő immobil fiatalok}

A központi mag identifikálásának módszertani problémáinál érdemes figyelembe venni Moliner (1994) javaslatát, mely szerint a központi kogníciókat mennyiségi és minőségi tulajdonságok jellemzik. A centrális elemek kvalitatív_tulajdonságai közvetlenül a szociális reprezentáció elméletéből erednek és a központi helyzetet biztosítják. Ebben az értelemben egy adott kogníció azért központi, mert szoros kapcsolatban van a reprezentáció tárgyával, szimbolikus érték és asszociatív erő jellemzi. A centrális elemek kvantitatív tulajdonságai a kvalitatívból erednek, azok következményei. Ezek az elemek „kiugrásként” (saliency) jellemezhetők: például milyen gyakran és /vagy azonnal mutatják a reprezentáció tárgyát és hány kapcsolatot tartanak a reprezentáció más elemeivel.

Az általunk követett egyik konkrét empirikus módszer (Verges 1992) eredeti verzióját átalakítva - egyfajta fordított logika alapján - az interjú szövegek feldolgozása két dimenzióban történt. Az első elemzési szakasz során azokat a szövegblokkokat gyüjtöttük ki, amelyekben az „én” személyes névmás szerepelt és legfeljebb három szóval (vagy értelmezhető narratív reagálással) asszociációnak (Én identitás) tekinthető. A másik elemzési dimenzióban nem az „én” névmás előfordulása, hanem az alanyra és/vagy a falura vonatkozó szubjektív viszonyulást és értékelést kifejező szövegrészeket (Lokális identitás) emeltük ki. Mindkét elemzési dimenzió során - a szöveg kontextusában értelmezve - az alanyok pozitív, semleges vagy negatív értékelésének kódolását is elvégeztük. Ez lényegében a feltárt direkt („én” személyes névmás előfordulása) és implicit (a lokális identitásra utaló, kvázi én-asszociációk) jelentések közötti hasonlóságok alapján értéktartalmú szemantikai kategóriákba sorolást jelentette. Az adatelemzés során a következő két kritériumot használtuk: 1. Az értékelési kategóriák (pozitív, semleges, negatív) a direkt „én” asszociációk és a Lokális identitásra utaló külön-külön rögzített előfordulási gyakoriság; 2. Az értékelési kategóriákon belül az előforduló asszociációk értékelésének előfordulása. A kettős elemzés alapja az volt, hogy az értékelési gyakoriságok magasabb előfordulási gyakorisága és a gyakrabban előforduló asszociációk számának együttes figyelembevételének köszönhetően az ilyen asszociáció-típusok nagyobb valószínűséggel tartoznak a központi maghoz. Az értékeléseket 1-től 3-ig súlyoztuk, annak megfelelően, hogy milyen értékeléssel minősítették a tényleges „én” és a lokális idenitásra vonatkozó potenciális „én” asszociációkat (a magasabb pont pozitívabb értékelést jelentett). Ha az Én identitás és a Lokális indentitás szociális reprezentációira vonatkozó súlyozott asszociációk értékelésének átlagos gyakoriságát és a teljes, differenciálatlan szövegre - az Én-identitiás és Lokális identitás összevont - vonatkozó asszociációk előfordulásának átlagát vesszük alapul, akkor a szociális reprezentáció típusokat az asszociációkat következő négy csoportba lehetett besorolni: 


\section{TEMATIKUS TANULMÁNYOK - Községekben élő immobil fiatalok}

1. táblázat. Az asszociációs kategóriák csoportosítása az értékelés és előfordulási gyakoriság alapján

\begin{tabular}{|c|c|}
\hline $\begin{array}{c}\text { 1. csoport } \\
\text { Átlag feletti értékelés } \\
\text { Átlag feletti előfordulás }\end{array}$ & $\begin{array}{c}\text { 2. csoport } \\
\text { Átlag feletti értékelés } \\
\text { Átlag alatti előfordulás }\end{array}$ \\
\hline $\begin{array}{c}\text { 3. csoport } \\
\text { Átlag alatti értékelés } \\
\text { Átlag feletti előfordulás }\end{array}$ & $\begin{array}{c}\text { 4. csoport } \\
\text { Átlag alatti gyakoriság } \\
\text { Átlag alatti előfordulás }\end{array}$ \\
\hline
\end{tabular}

Forrás: Verges (1992)

A bal felső sarokban lévő kategóriák - a leginkább kedvezően értékelt és legygyakrabban előforduló - nagyon valószínű, hogy a központi maghoz tartoznak. Ezzel szemben azok a kategóriák, amelyek az alsó jobb negyedben vannak nagyobb valószínűséggel periferiális helyzetűek. A másik két negyedbe sorolt kategóriákat olyan periferiális kognícióknak tekinthetjük, amelyek szorosan kapcsolódnak a központi maghoz.

Az egyes csoportokat jellemző értékelés és előfordulási átlagok a következők:

\section{2. táblázat}

Az asszociációk kategóriáira vonatkozó előfordulási és értékelés átlagok

\begin{tabular}{|l|r|}
\hline Én identitásra vonatkozó asszociációk előfordulásának átlaga & 1.16 \\
\hline Lokális identitásra vonatkozó asszociációk előfordulásának átlaga & 8.09 \\
\hline Én identitásra vonatkozó asszociációk értékelésének átlaga & 4.02 \\
\hline Lokális identitásra vonatkozó asszociációk értékelésének átlaga & 23.92 \\
\hline $\begin{array}{l}\text { Identitásra (Én és Lokális identitás) vonatkozó asszociációk előfor- } \\
\text { dulásának átlaga }\end{array}$ & 10.07 \\
\hline $\begin{array}{l}\text { Identitásra (Én és Lokális identitás) vonatkozó asszociációk } \\
\text { értékelésének átlaga }\end{array}$ & 28.13 \\
\hline
\end{tabular}

Forrás: Saját szerkesztés

Az Én identitás és a Lokális identitás értékelésének lényegesen különböző átlaga annak köszönhető, hogy az én identitás esetén a három (pozitív, semleges, negatív) értékelési pontszám összegének eloszlása során 43 százalék volt az egyik esetben sem értékelt asszociációk aránya, míg a Lokális identitás esetén mindez csupán 2 százalék. Egyúttal ez azt jelenti, hogy az alanyok válaszaiban jelentősen nagyobb számban fordultak elő a Lokális identitásra vonatkozó konkrét, vagy nem konkrét, de lokális tartalmú asszociációk. Ennek megfelelően az előfordulások átlaga is je- 


\section{TEMATIKUS TANULMÁNYOK - Községekben élő immobil fiatalok}

lentősen eltér, mivel a Lokális identitás asszociációinak átlagával (8.09) szemben az Én-identitás asszociációk előfordulásának átlaga 1.16.

A szociális reprezentáció alapján történő elemzés eredményei szintén utalnak az affektív kötődésre, de nem meghatározó jelleggel. ${ }^{5}$

A következőkben az Én- és Lokális dimenziókat egyaránt tartalmazó, az identitás szociális reprezentációja alapján elkülöníthető négy csoport (1. centrális/core, 2-3. átmenet, 4. periféria) közül az identitás leginkább (core) és a legkevésbé (periféria) meghatározó jelentéstartalmakat kifejező csoportok megoszlására támaszkodunk. A projektben résztvevő hallgatók által kialakított kategóriák (változók) a vizsgálat tematikájához illeszkednek. A következő elemzésünk arra próbál választ adni, hogy a válaszadók releváns (fontosabb) almintáit hogyan jellemzi az én- és lokális elemekre épülő identitás szociális reprezentációja alapján elkülönült csoportok.

Eredményeink szerint a nőkre, a fiatalokra, a diplomásokra és a házasságban élőkre jellemző leginkább, hogy az ezen csoportokat az átlagosnál nagyobb mértékben jellemzi az interjúk alapján konstruált én- és lokális identitás szociális reprezen-

${ }^{5}$ ÉN IDENTITÁS / Pozitív jelentéstartalom: „Gondolkodásmód, az hogy mindenki bele akar szólni a másik életébe, mindenki jogot formál arra, hogy én megmondom a másiknak, hogy mi a jó és hogy élje az életét.” „[S]okan hívnak hogyha tegyük fel elromlik a gépük. (számítógép) Akkor én csinálom meg, én tartom úgymond karban a gépet.” „Vannak olyan barátaim, akikkel tartós kapcsolatot ápolok, én bármiben és bármikor segítek nekik, ahogy ők is nekem.” Semleges jelentéstartalom: „Én ide születtem Sajógalgócra.” „Hát figyelj, én azt mondom, hogy - már ha ezt így lehet mondani - kisebbség itt a mi falunkban egyáltalán nem is mutatkozik meg.” „Ritka a konfliktus. Az én családomat néha érinti.” Negatív jelentéstartalom: „Hát figyelj, úgy vagyok vele, ha nem keresnek, én sem keresek senkit.” „Én nem szeretek a gondjaimról beszélni másoknak.” „Nem szeretnek a faluban az emberek, és én sem őket”. „Egyedül én vagyok itthon lébecoló.” „Hát a rokonokkal azért elég felszínes a kapcsolat, szerintem nem olyan mély, vagy mit tudom én.”

LOKÁLIS IDENTITÁS / Pozitív jelentéstartalom: „Csendes, nyugodt - már amikor, az én véleményem szerint tökéletes. Semmi probléma nincsen, nincsenek veszekedések, meg a környezet is jó.” „Szerintem Kisgyőr a legszebb a három falu közül. Miben más azt nem tudom...” „Ez egy csendes település. Nagyon barátságosak az itt élő emberek. Az idősebbek is”. „[N]em nagy távolság, meg vannak közelebb is kisebb városkák, de jó a levegő, jó helyen van, tehát jók az adottságok, mint mezőgazdaságilag, mint mindenhogy, én szeretem.” „[B]ulis hely a város, nagyon jó, nagyon sok lehetőség van. De én személy szerint nem laknék bent, hanem egy városnak a szélén laknék. Tehát nekem szükségem van arra, hogy legyen helyem, legyen virág, legyen zöld, tehát, hogy vidéki hangulat legyen.” „A szülők milyen megfontolások alapján választották ki az alapfokú iskolát? Itt van helybe, minden nap haza lehetett járni, nem kellett kollégium.” Semleges jelentéstartalom: „Mondjuk én nyilván jól jártam annó, amikor bekerültem a konyhára.” „Hát régebben még annyira nem szerintem, mondjuk én még akkor nem éltem, mert 97-ben születtem, nem nagyon tudom úgymond...” „Változó, kivel, hogy tartjuk a kapcsolatot. Van, akivel jobban, szorosabban tartjuk a kapcsolatot. „Van, akivel viszont nagyon gyengén vagy nagyon ritkán találkozunk vele.” „Inkább munkalehetőség miatt, mert itt a településen nem nagyon van, meg a környező régió, környező településeken se nagyon van.” „Hát nem, mi már nagyon régóta itt lakunk... Úgyhogy mindenki, törzsgyökeres szentandrásiak vagyunk.” „Kevés a roma, tehát szívesen járnak ide az emberek.” „Régebben meg volt a Vay Ádám kastély és hát, az egész falu szinte odajárt a grófnak csinálni, dolgozni valamit, ki mit. Én ilyenekről tudok.” Negatív jelentéstartalom: „Hát így velem egykorú fiatal, vagy plusz, minusz 2-3 év nem is nagyon van.” „Hát édesanyám, két testvérem, nővérem meg a bátyám, sajnos édesapám már elhunyt, így meg én. Jómagam.” „Hát, én szerintem nem vagyok annyira fontos. Én csak azért szeretek falun lakni, mert ehhez szoktam hozzá.” „[E]zek mezőgazdasági vállalkozáson belüli problémák. Ez a jelentgetés, ez a neked ennyi van, nekem miért nincs, azért a száját jártassa. Ez az irigység, aha." 


\section{TEMATIKUS TANULMÁNYOK - Községekben élő immobil fiatalok}

tációja. A szocio-demográfiai jellemzőket tekintve, különösen az életkor és az iskolai végzettség csoportok között van számottevő eltérés (3-6. táblázat).

3. táblázat. Nem / és az identitás szociális reprezentációja (sor-százalékban)

\begin{tabular}{|l|c|c|}
\hline & Core & Periféria \\
\hline Férfi & 29 & 71 \\
\hline Nő & 41 & 59 \\
\hline
\end{tabular}

Forrás: Saját szerkesztés

4. táblázat. Életkor / és az identitás szociális reprezentációja (sor-százalékban)

\begin{tabular}{|l|c|c|}
\hline & Core & Periféria \\
\hline $18-21$ éves & 50 & 50 \\
\hline $22-25$ éves & 30 & 70 \\
\hline
\end{tabular}

Forrás: Saját szerkesztés

5. táblázat. Iskolai végzettség / és az identitás szociális reprezentációja (sor-százalékban)

\begin{tabular}{|l|c|c|}
\hline & Core & Periféria \\
\hline Legfeljebb nyolc általános & 38 & 63 \\
\hline Szakmunkás & 20 & 79 \\
\hline Középfok & 39 & 62 \\
\hline Felsőfok & 64 & 36 \\
\hline
\end{tabular}

Forrás: Saját szerkesztés

6. táblázat. Családi állapot / és az identitás szociális reprezentációja (sor-százalékban)

\begin{tabular}{|l|c|c|}
\hline & Core & Periféria \\
\hline Házas & 67 & 33 \\
\hline Élettárs & 20 & 80 \\
\hline Párkapcsolat & 20 & 80 \\
\hline Elvált & 0 & 100 \\
\hline Nőtlen & 36 & 64 \\
\hline Egyedül él & 44 & 56 \\
\hline
\end{tabular}

Forrás: Saját szerkesztés 


\section{TEMATIKUS TANULMÁNYOK - Községekben élő immobil fiatalok}

A projekt alapvető kérdéseihez leginkább kapcsolódó változók (csoportok) és az identitás közötti kapcsolatok arra utalnak, hogy a mobilitás (immobilitás) alapján elkülönült csoportok (mobil családtag, hosszabb távollét) között nem tér el lényegesen a központi mag (illetve a periferiális jelentéseket képviselő kategória) megoszlása (7-8. táblázat).

7. táblázat. Volt-e hosszabb időben távol a falutól / és az identitás szociális reprezentációja (sor-százalékban)

\begin{tabular}{|l|c|c|}
\hline & Core & Periféria \\
\hline Nem volt & 30 & 70 \\
\hline Volt & 37 & 63 \\
\hline
\end{tabular}

Forrás: Saját szerkesztés

8. táblázat. Mobil családtag / és az identitás szociális reprezentációja (sor-százalékban)

\begin{tabular}{|l|c|c|}
\hline & Core & Periféria \\
\hline Van mobil tag & 34 & 66 \\
\hline Nincs mobil tag & 38 & 62 \\
\hline
\end{tabular}

Forrás: Saját szerkesztés

A tapasztalt mobilitással szemben az individuális jellemzők alkotják a harmadik változócsoportot: a mobilitás/immobilitás tervei (az immobilitás indoklása, mobilitási tervek) és az affektív viszonyulás (a falu szeretete), valamint a network sajátosságai (munkahely helye, kapcsolatháló). Az eredmények egyik része nem meglepő, mivel a faluhoz kapcsolódó pozitív érzelmek, a kiterjedt kapcsolatok az identitás szociális reprezentációjának markáns és meghatározó jellemzőivel van szoros kapcsolatba. Ezzel szemben nem várt eredménynek tekinthető, hogy az immobilitás leginkább olyan identitás reprezentációval írható le, amely a falu nyújtotta lehetőségeket képviseli, hasonlóan a tervezett elköltözési szándékhoz (9-13. táblázat).

9. táblázat. Miért maradt a faluban / és az identitás szociális reprezentációja (sor-százalékban)

\begin{tabular}{|l|c|c|}
\hline & Core & Periféria \\
\hline A falu szeretete & 35 & 65 \\
\hline Kényszer & 32 & 68 \\
\hline Lehetőség & 46 & 54 \\
\hline
\end{tabular}

Forrás: Saját szerkesztés 
www. metszetek.unideb.hu

\section{TEMATIKUS TANULMÁNYOK - Községekben élő immobil fiatalok}

10. táblázat. Elköltözési terv / és az identitás szociális reprezentációja (sor-százalékban)

\begin{tabular}{|l|c|c|}
\hline & Core & Periféria \\
\hline Van terv & 46 & 54 \\
\hline Nincs terv & 29 & 71 \\
\hline
\end{tabular}

Forrás: Saját szerkesztés

11. táblázat. A falu szeretete / és az identitás szociális reprezentációja (sor-százalékban)

\begin{tabular}{|l|c|c|}
\hline & Core & Periféria \\
\hline Szereti & 39 & 61 \\
\hline Inkább szereti & 100 & 0 \\
\hline Nem szereti & 36 & 64 \\
\hline
\end{tabular}

Forrás: Saját szerkesztés

12. táblázat. A munkahely helye / és az identitás szociális reprezentációja (sor-százalékban)

\begin{tabular}{|l|c|c|}
\hline & Core & Periféria \\
\hline Falun belül & 32 & 68 \\
\hline Falun kívül & 30 & 70 \\
\hline Nincs munkahely & 55 & 45 \\
\hline
\end{tabular}

Forrás: Saját szerkesztés

13. táblázat. Kapcsolatháló / és az identitás szociális reprezentációja (sor-százalékban)

\begin{tabular}{|l|c|c|}
\hline & Core & Periféria \\
\hline Gazdag & 56 & 44 \\
\hline Átlagos & 21 & 79 \\
\hline Beszúkült & 39 & 61 \\
\hline
\end{tabular}

Forrás: Saját szerkesztés 


\section{TEMATIKUS TANULMÁNYOK - Községekben élő immobil fiatalok}

\section{Összegzés}

Összegzésként azt mondhatjuk, hogy a vizsgált települések ifjúságát jellemző identitás szociális reprezentációja a szocio-kulturális sajátosságokat tekintve nem meglepő, viszont a mobilitás/immobilitás változók esetében az eredmények nem egyértelműek. Ha a mobilitásról vannak tapasztalatok, akkor az identitás szociális reprezentációját jól körülírható, markáns elemek jellemzik. Ezzel szemben a vágyak és tervek világa ellentmondásos, mondhatnánk inkonzisztens: több esetben az identitás elemek csupán periferiális pozíciót töltenek be az identitás szociális reprezentációjában.

A lakóhelyhez kapcsolódó egyértelmű érzelmi kötődés esetén kisebb mértékben jellemző az én- és lokális identitás szociális reprezentációja, míg a kevésbé egyértelmű kötődés esetén az identitás reprezentáció jóval erősebb. Mindez szinkronban van azzal, hogy azok körében akik tervezik az elköltözést az identitás szociális reprezentációjában nagyobb mértékben meghatározók a mérés során kialakított identitás elemek. Az elköltözési szándék és az identitásban megnyilvánuló kötődés feltehetően sajátos ambivalenciát jelent: a lakóhelyhez kapcsolódó szubjektív és pozitív érzelmi jellemzők (család, rokonság, gyermekkor) egyúttal részei a lokális identitásnak is. Azonban az érzelmi kapcsolódás nem minden esetben pozitív és egyértelmủ, ezért az én- és lokális identitás szociális reprezentációját is nagyobb arányban jellemezhetik a perifériális elemek.

Mindezek (részbeni) magyarázatára olyan kutatás válaszolhat, amely nem az interjúszövegek feldolgozása, hanem a nyitott asszociációk alapján értelmezi a különböző identitás-típusok szociális reprezentációját. Adott a következő feladat.

\section{Irodalom}

A. Gergely A. (1996): Identitás és etnoregionalitás. Budapest, MTA PTI Etnoregionális Kutatóközpont

A. Gergely A. (é.n.): A totális társadalmi tények mint térhasználati és identitásmódok. (Rövid áttekintés a helyi tudás tartalmáról) Antropológiai Internetes Portál http://www.antroport.hu/lapozo/tanulmanyok.html\#agatotalis Utolsó letöltés: 2011.04.04.

Abric, J-C. (1994a) : Les représentations sociales: aspects théoriques. In: J-C. Abric (ed.) Pratiques sociales et représentations. Paris, Presses Universitaires de France, 11-35.

Asher, S. B. - Wagner, W. - Orr, E. (2006): Thinking groups: Rhetorical enactment of collective identity in three Israeli Kibbutzim. Asian Journal of Social Psychology, $9,112-122$. 


\section{TEMATIKUS TANULMÁNYOK - Községekben élő immobil fiatalok}

Bakó B. (2003): „Itthon vagyunk megszokva, ideköt minden” Egy barcasági magyar közösség lokális identitástudatáról és interetnikus kapcsolatrendszeréről. In: Bakó B. (szerk.): Lokális világok. Együttélés a Kárpát-medencében. MTA Társadalomkutató Központ, Budapest, 165-191.

Bőhm A. (2000): Térségi identitás Magyarországon, In: Bőhm A. et al. (szerk.): Területfejlesztés és közigazgatás-szervezés. MTA, Budapest

Bőhm A. - Pál L. (1987) (szerk.): A helyi hatalom múködése. MSZMP KB Társadalomtudományi Intézete, Budapest

Bruner, J. S. (1990): Acts of Meaning. Cambridge, MA, Harvard Univ. Press

Csatári B. (1989) A Tiszazug kistérségi problémái. Kutatási jelentés, kézirat. Kecskemét, MTA RKK Településkutató Csoport

Gyáni G. (2008): Identitás, emlékezés, lokalitás. 2000. 20: (6), 19-27.

Hamar A. - Murányi I. - Szoboszlai Zs. (1997): Az alföldi társadalom innovatív csoportjai. Alföld Kutatási Program II. Kutatási jelentés, Kézirat, MTA RKK ATI, Szolnok

Csepeli Gy. (1992): Nemzet által homályosan. Budapest, Századvég

Enyedi Gy. (1991): A lokalitás szerepe a modern társadalmakban. JUSS, 4.

Erik H. Erikson (1991): Identitásválság önéletrajzi vetületben. In: A fiatal Luther és más írások. Budapest, Gondolat Könyvkiadó

Erős F. (1996): Előszó. In: Erős F. (szerk.): Azonosság és különbözőség. Budapest, Scientia Humana. 5-8.

MacIntyre AC. (1984): After Virtue: A Study in Moral Theory. Notre Dame, IN: Univ. Notre Dame Press Meier, K. - Kirchler, E. (1998): Social representations of the euro in Austria. Journal of Economic Psychology 19., 755-774

Krappmann L. (1980): Az identitás szociológiai dimenziói. Szociológiai Füzetek 21.

Köteles S. - Varga Cs. (1988) (szerk.): A helyi cselekvés. JAK füzetek 38. Magvető, Budapest

Millward, L. J. (1995): Contextualizing social identity in considerations of what it means to be a nurse. European Journal of Social Psychology, Vol. 25., 303-324.

Moscovici, S. (1984): The Phenomenon of Social Representations. In: Farr, Robert M. and Moscovici, S. (eds.) Social Representations. 3-70. Cambridge University Press, Cambridge

Moscovici, S. (1988): Notes Towards a Description of Social Representations. European Journal of Social Psychology, 18, 211-250.

Moliner, P. (1994) : Les métodes de répérage et d'identification du noyau des représentations sociales. In: C. Guimelli (ed.) Structures et transformations des représentations sociales. Neuchâtel: Delachaux et Niestlé, 199-232. 


\section{TEMATIKUS TANULMÁNYOK - Községekben élő immobil fiatalok}

Murányi I. - Szoboszlai Zs. (1998): Ifjúsági életmód és szokásvizsgálat Jász-Nagykun-Szolnok megyében. MTA RKK, Szolnok

Murányi I. - Szoboszlai Zs. (1999): Sikeres városok, magasan, illetve alacsonyan fejlett települések az Alföldön. MTA RKK, Szolnok

Nánásiné Tóth É. (1996): Kötődések a városhoz. Kutatási jelentés. Kézirat. Kecskemét, MTA RKK ATI

Olick, J. K. - Robbins, J. (1998): SOCIAL MEMORY STUDIES: From „Collective Memory" to the Historical Sociology of Mnemonic Practices Annual Reviews Sociology, 1998. $24: 105.40$

Pataki F. (1982): Az én és a társadalmi azonosságtudat. Budapest, Kossuth Kiadó

Pálné Kovács I. (2000): Régiók Magyarországa: utópia vagy ultimátum? In: Horváth G. -Rechnitzer J. (szerk.): Magyarország területi szerkezete és folyamatai az ezredfordulón. Enyedi György 70. születésnapjára. MTA RKK, Pécs

Purkhardt, S. C. (1993): Transforming Social Representations: A Social Psychology of Common Sense and Science, Routledge, London and New York

Sá, C. P. (1995): The Central Nucleus Approach to Social Representations. Paper was presented in the XXV Interamerican Congress of Psychology, San Juan de Puerto Rico

Tajfel, H. - Turner, J. (1979): An integrating theory of intergroup conflict. In: W. Austin - S. Worschel (eds.): The social psychology of intergroup relations (pp. 33-47). Monterey, CA: Brooks/Cole

Tajfel, H. (1982): Social psychology of intergroup relations. Annual Review of Psychology, 33, 1-39.

Tajfel, H. (1978): Social categorization, social identity, and social comparison. In: H. Tajfel (ed.): Differentiation between social groups (pp. 61-76). New York: Academic Press

Verges, P. (1992) L'évocation de l'argent: une méthode pour la définition du noyau central d'une représentation. Bulletin de Psychologie, 45 (405), 203-209.

Vincze 0. - Kőváriné Somogyvári I. (2003): A nemzeti identitás reprezentációja a sikeres történelmi regényekben. Magyar Tudomány, 1. 55-66. 